\title{
Female Migrant Entrepreneurs in Vienna: Mobility and its Embeddedness
}

\author{
Petra Dannecker $\cdot$ Alev Cakir
}

(C) The Author(s) 2016. This article is published with open access at Springerlink.com

\begin{abstract}
This article discusses how female 'migrant' entrepreneurs present and connect mobility to their social realities and how spatial mobility influence their economic activities, social interactions and subjectivities and the way how female 'migrant' entrepreneurs experience and define social mobility. This perspective allows to critically analyze the shortcomings of the debates on 'ethnic' entrepreneurship and the gender bias which still dominates the mainstream debates. Based on qualitative interviews with female migrant entrepreneurs in Vienna it can thus be shown that mobility does not only become an important marker for boundary drawing but gets rationalized by the female entrepreneurs as an important qualification and a means for social mobility.
\end{abstract}

Keywords 'ethnic' entrepreneurs · Female migrant entrepreneurs · Mobility · Gender · Embeddedness

P. Dannecker $(\bowtie)$

Institut für Internationale Entwicklung, Universität Wien,

Sensengasse 3, Stiege 2, 1090 Wien, Austria

E-Mail: petra.dannecker@univie.ac.at

A. Cakir

Institut für Politikwissenschaft, Universität Wien,

Hofburg, Batthyanystiege 2, 1010 Wien, Austria

E-Mail: alev.cakir@univie.ac.at 


\section{Migrantische Unternehmerinnen in Wien: Mobilität und Embeddedness}

Zusammenfassung Wie migrantische Unternehmerinnen in Wien Mobilität erfahren und rationalisieren und wie Mobilität ihre ökonomischen Aktivitäten, sozialen Interaktionen und Subjektivierungen beeinflussen, steht im Zentrum dieses Beitrags. Wie räumliche und soziale Mobilität verknüpft werden, zeigen die qualitativen Interviews mit migrantischen Unternehmerinnen. Dabei wird deutlich, dass nicht ,Ethnizität‘ zur Konstruktion von Differenz herangezogen wird, sondern Mobilität, um sich einerseits von den ,immobilen anderen ${ }^{\circ}$ abzugrenzen, andererseits aber auch als Qualifikation definiert wird und als Voraussetzung für soziale Mobilität.

Schlüsselwörter ,Ethnische' Ökonomie · Migrantische Unternehmerinnen · Mobilität $\cdot$ Gender $\cdot$ Embeddedness

\section{Introduction}

"I think nearly all self-employed people in Vienna are migrants; locals are too afraid to open a business ..." says Sara, who owns a Thai massage business in Vienna. Sara is one of the $37 \%$ of Viennese entrepreneurs who have a 'migration background' (Alteneder and Wagner-Pinter 2013; Stadt Wien 2012). Even though statistically the number of such entrepreneurs has not yet outpaced the number of so-called local entrepreneurs, for Sara as well as for many other female entrepreneurs with a socalled migration background (whom we interviewed for the research project ${ }^{1}$ ), spatial mobility turned out to be an important resource for and of self-employment and a means to position themselves within complex societal configurations. The mobility histories of the female entrepreneurs or in the case of those who have not migrated themselves, those of their families, have influenced their decisions to become selfemployed, and are presented as a specific 'qualification' and a means for distinguishing themselves from the immobile 'others'. Taking risks, working hard, and being flexible and innovative are attributes that were connected in many interviews to mobility, even for those who have not moved spatially, showing that people can be mobile without in fact moving (Salazar and Smart 2011, p. iv). Mobility is thus presented as a means of "act[ing] in difficult and uncertain circumstances and describing how they disentangle themselves from confining structures, plot their escape and move towards better positions" (Vigh 2009, p. 419).

This empirical snapshot indicates the main aim of the paper; namely, to analyse how mobility influences the economic activities, social interactions and subjectivities of the female migrant entrepreneurs (Sheller and Urry 2006). For the women studied their or their family mobility histories turned out as an important frame of action and

\footnotetext{
${ }^{1}$ The research project on female migrant entrepreneurs in Vienna is one of the projects that constitute the Research Platform 'Mobile Cultures and Societies', which is funded by the University of Vienna and started in 2013. The aim of the interdisciplinary platform is to analyze terms and theoretical concepts such as mobility, diasporisation, identity and hybridity and to develop them further (see www.mobilecultures. univie.ac.at).
} 
boundary-drawing, connected to important ruptures and certain 'qualifications'. It is therefore the interface between the 'moving out' (spatial mobility) and the 'moving up' (social mobility) which is in the centre of our academic interest. Through scrutinizing how the spatial mobility of the women or of their families is experienced and derives meaning from its embeddedness within societies, cultures, politics and histories (Cresswell 1999), we aim to go beyond mainstream studies on migration and/ or social mobility focusing primarily on integration and occupational or educational attainments. Instead, we intend to show how different forms and concepts of mobility are perceived and negotiated by the actors, how they become meaningful and how they influence their life worlds. Drawing upon phenomenological concepts (Schütz 1971; Schütz and Luckmann 1979), will allow to show how their mobility histories are experienced, rationalised and 'used' by those female migrants who have become entrepreneurs and how their mobility histories became a resource and a marker of difference. The way they experience mobility and rationalise and present it cannot, however, be analysed without taking the societal context into account. In Austria as elsewhere migrants are, through collective processes, increasingly constructed by the so-called majority population as the 'other', and a security risk (Huysmans 2000). Female migrants in particular are considered keepers of 'traditional cultures' and a threat to the collective need for homogeneity and cultural identity (Nuscheler 2004, p. 23). Given the relatively high unemployment rate among migrant women, they are furthermore perceived as potentially 'exploiting' the Austrian welfare system (Kofman et al. 2015). How migrants, defined as 'ethnic other', challenge these 'groupist assumptions" (Pfaff-Czarnecka 2013, p. 8) and rationalise these constructions and experiences in their practices, daily interactions and economic activities, as well as whether and how mobility becomes meaningful and is negotiated, will be discussed. Thereby, as Brubaker (2002) argues it is crucial to examine how and under which conditions people identify themselves or perceive themselves as 'others' and interpret or experience the world in ethnic, racial or national terms rather than other terms (Brubaker 2002). As will be analysed in the case of the female migrant entrepreneurs rather mobility than ethnicity became an identity marker of female migrant entrepreneurs for differentiating themselves from the so-called immobile 'others'.

The focus on mobility in this paper thus follows different rationalities as does the focus on female migrant entrepreneurs studied. In the following section we will shortly discuss the mainstream literature on 'ethnic entrepreneurs' and some critical approaches to it, showing then that not 'ethnicity' but mobility is perceived as a resource and an important marker for difference. Further, we will also provide some methodological reflections concerning our research. Some of the empirical findings will then be presented in section four before concluding. In our study neither the women nor we 'romanticize' mobility or want to 'romanticize' mobility, a criticism the current 'mobility turn' (Sheller and Urry 2006) respectively the discourses on mobility are confronted with (see f. ex. Friedman 2002). Instead, we intend to present how mobility gets negotiated and embedded by the actors, in this case female migrant entrepreneurs, to position themselves. 


\section{Who is a migrant or 'ethnic' entrepreneur?}

Research on migrant entrepreneurship is by now primarily embedded in the concept of 'ethnic entrepreneurship'. In this field, various approaches aiming at a nuanced picture have been developed in recent decades. Until the 1990s, 'culturalist' approaches focusing exclusively on the cultural and religious values inherent to certain groups dominated explanations of why some 'groups' are more inclined to business than others. Since then, especially with regard to Europe, more integrated approaches focusing on opportunity structures, ethnic capital, social mobility and barriers in the host societies, as well as on the social resources of ethnic communities, have broadened the discussion and debate (Waldinger et al. 1990; Kloosterman and Rath 2001; Light and Gold 2000). It is either spatial mobility/migration or ethnic boundary-drawing that constitutes or 'makes' 'ethnic entrepreneurs'. These two 'groups' are hardly ever differentiated, nor are gender dimensions taken into account. Recently, these approaches to and literature on 'ethnic entrepreneurship' have been criticised from various perspectives:

First, the way the term 'ethnic' or 'ethnicity' is used in the literature on and approaches to 'ethnic entrepreneurship' is increasingly under review. The construction and taken-for-granted of 'ethnic communities' as well as the use of 'ethnicity' as a category is especially criticized for homogenizing 'ethnic communities' and constructing them as a fixed and given de-territorialized group (Brubaker 2002). Taking 'ethnicity' as an important social category of the post-immigration landscape (Fox and Jones 2013) leads to the assumptions of differences between, for example, 'ethnic' and 'local' entrepreneurs and, by extension, female migrant and 'local' female entrepreneurs, and hence to explanations of migrants' exceptional, ethnic entrepreneurial behaviour that reference cultural/ethnic traditions, moral frameworks, or behaviour patterns (Glick Schiller and Caglar 2013; Wimmer and Glick Schiller 2003). Whether ethnic identities are central to people in general and so-called ethnic entrepreneurs in particular is not problematized. Using the category 'ethnicity' methodologically as well as conceptually tends therefore to overlook the fact that ethnic classifications are highly contextual, relational and dynamic (Brubaker 2002, p. 167). It is the 'ethnic' positioning by majoritarian forces, not the 'ethnicity' itself, that influences migrants' resources as well as possibilities (Anthias and Mehta 2003), whereas the self-identification of so-called 'ethnic others' is not considered. This 'ethnic lens' (Wimmer and Glick Schiller 2003), which characterises approaches to 'ethnic entrepreneurship', does not, furthermore, take mobility into account. How, for example, mobility influences or permanently changes 'ethnic' or religious beliefs, practices and networks, and whether mobility is an important frame of reference for identity construction, self-identification or economic activities, is not analysed. As will be shown later, it is not 'ethnic' identities that were highlighted in the interviews, but mobility as a marker of difference, a 'resource' for social mobility, a 'qualification' economically as well as socially, and a frame of reference for self-identification and imagination.

Second, the prevalent focus on one nation state in the literature on 'ethnic entrepreneurs' is criticised. The pluri-local, transnational, interactive relationships of migrants and their descendants were and are largely ignored and not systematically explored (Portes et al. 2002, p. 284; Goebel and Pries 2006, p. 264) due to the fact 
that methodological nationalism (Wimmer and Glick Schiller 2003) has been and still is prevalent. Due to this focus, it has long been overlooked that many migrant businesses depend on regular contact with their countries of origin or, as for example Zhou (2004) argues, on social networks across space. Neither has it been discussed that so-called local 'ethnic' economies are increasingly part of global production (Portes et al. 2002). Newer approaches focus on the role of transnational networks and activities, or transnational social capital. Different forms of mobility, like flows of material resources and information, travel, or various types of transnational 'ethnic' businesses (like migrant return enterprises in their so-called countries of origin or transnational firms) have thus been discussed and analysed. Seldom, however, transnational dimensions beyond the economic, like political or cultural activities (Fauser et al. 2015) are taken into account; nor is it discussed for whom which form of mobility is possible, or whether these forms of mobility facilitate disentangling from confining structures or framing migrant's self-perception and/or social mobility. Furthermore, whether and how social categories like gender influence transnational strategies and activities is also a neglected issue. We assume, as for example the study of Ambrossini (2012) shows, that transnational activities are different, less relevant and even difficult to maintain for female migrant entrepreneurs, and that the transnational ties of female migrants might focus more on the cultural rather than the economic domain due to, for example, gender relations (or respective groups' newly negotiated gender relations due to mobility). Given that gender shapes the ways networks are put together and used (Hanson and Blake 2009, p. 137), it can be further assumed that women's networks contain a higher proportion of kin and neighbours than men's networks do, and that female entrepreneurs are less spatially mobile than their male counterparts. ${ }^{2}$ This, it is assumed, will influence the possible sectors and the nature of activities in which female migrant entrepreneurs get involved, as well as the meaning mobility, especially social mobility has for them.

Third, and on a more general level, the functional notion underlying most of the approaches to ethnic entrepreneurship, i. e. market-based logic and the focus on entrepreneurship as a desirable economic activity that leads to the integration of migrant 'others' (Verduijn and Essers 2013, p. 614), is criticised. In Austria as elsewhere, language is defined as the most important factor for the successful 'integration' of migrants, but is closely followed by economic success. Accordingly, self-employment is seen as a positive migrant economic activity and programmes have been founded in Austria as elsewhere to stimulate migrant entrepreneurship. The Austrian Chamber of Commerce, for example, has initiated a mentoring programme for migrant entrepreneurs, ${ }^{3}$ and the Vienna Business Agency has set up $\mathrm{Mingo}^{4}$, a counselling centre that takes an active role in stimulating and supporting the initiatives of individual migrant entrepreneurs. According to a study by the Austrian Chamber of Labour in 2014 (see Schmatz and Wetzel 2014), however, many businesses run by migrant entrepreneurs have low added value and do not last. Despite this, neither

\footnotetext{
${ }^{2}$ For further information on female entrepreneurs' social networks, see Garcia-Díaz and Carter 2009; Klyver and Grant 2010; Reevy and Maslach 2001.

${ }^{3}$ https://www.wko.at/Content.Node/Mentoring/Startseite---Mentoring.html.

${ }^{4}$ https://www.mingo.at.
} 
the conviction that entrepreneurship is good nor its positive impact on integration (Verduijin and Essers 2013, p. 621) is questioned. Interestingly, some authors like Esser (2003) argue that, even though they might be important economic resources, transnational activities hinder successful integration, i. e. becoming assimilated, and a 'Western' kind of entrepreneur.

Most important to our rationale of choosing female migrant entrepreneurs, however, are female scientists' criticisms that studies on and rhetoric around 'ethnic entrepreneurship' by and large overlook the phenomenon's gendered character, i. e. that entrepreneurship typically has a masculine label attached to it (Verduijn and Essers 2013; Hancock et al. 2014). Although from the 1980s on feminists have argued that women are often used as a cheap and flexible source of labour (Phizacklea 1983; Anthias 1992), inequality and oppression of female labour in 'ethnic enterprises' has often been subsumed in the literature on 'ethnic entrepreneurs' under the euphemistic term of 'family labour', or deemed a necessary strategy for small enterprises to resolve problems (Borjas 1986). In recent years, critical studies by feminist researchers have focused on differences and relations of power within so-called 'ethnic' communities, and differences between migrant women and non-migrant women with regard to citizenship, economic and cultural differences have also influenced studies on female migrant entrepreneurs. However, the literature dealing with female migrant entrepreneurship is still thin and derivative (Halkias and Caracatsanis 2011, p. 4). Within the existing approaches, women entrepreneurs are no longer seen as dependant but conceptualised as actors, i. e. active protagonists navigating the complex dynamics between 'ethnic' communities and networks, labour market conditions and the cultural assignations of their host societies. The emerging literature on women entrepreneurs focuses on different aspects and dimensions, arguing from different theoretical backgrounds and using different methodological approaches. Nevertheless, some important strands of literature can be identified concerning different areas of investigation: First, there is an immanent focus on obstacles that migrant women entrepreneurs face due to gender, their status in the host society, and/or their 'ethnicity' influencing, for example, networking, access to resources, and human and social capital (Azmat 2013; Baycan-Levent 2010; Pio 2007; Erel 2010). Second, studies analyse whether women's self-employment leads to empowerment and integration or is primarily a reaction to labour market discrimination (Apitzsch 2003; Morokvasic 1991). Third, research targets the sectors in which migrant women are engaged and their entrepreneurial strategies, as well as the legal, institutional and political conditions that influence self-employment (Hillmann 1998; Volery 2007; Verduijn and Essers 2013). These studies show that migrant women entrepreneurs are not a homogeneous group and that, for instance, prior employment, education, or legal status are equally as relevant to their entrepreneurial efforts as gender relations in their countries of 'origin' and 'destination', 'ethnicity' and the support of institutions and organisations. 


\section{Methodological reflections - setting the scene}

In order to achieve the above objectives namely to sharpen the understanding of mobility by analysing and discussing the role mobility plays in the female migrant entrepreneurs orientation and positioning by taking the different societal contexts into account, a qualitative interpretive methodological approach was chosen. The research follows a Grounded Theory approach (Glaser and Strauss 1967) whereby the questions raised and assumptions made above, respectively how mobility gets negotiated and influenced female migrant entrepreneurs' economic strategies as well as their self-perception. The empirical process was from the beginning accompanied by several challenges:

First of all, theoretical sampling proved difficult since information on migrant entrepreneurship, particularly on female migrant entrepreneurs, is scarce and fragmented. Much of the existing literature on migrant entrepreneurship in Austria does not distinguish between male and female migrants. Instead, existing studies analyse the general 'ethnic' or migrant economy in Austria (Schmatz and Wetzel 2014; Aigner 2012a and b; Haberfellner 2003; Haberfellner and Böse 1999). Like in most other OECD countries, around one third of entrepreneurs in Austria are said to be migrants (Schmatz and Wetzel 2014, p. 1, L\&R Sozialforschung 2007), and are involved in different sectors and in a broad variety of economic activities. The majorities of migrant enterprises are small, without employees, and involved in trade or in the service or catering sectors. ${ }^{5}$ According to Schmatz and Wetzel (2014, p. 18 f.), the percentage of female migrant entrepreneurs in Vienna is lower than that of men, and is concentrated in the health and social sectors and in the service sector in general. Their study gives quite a differentiated overview, especially with regard to nationalities and areas of activity, thereby showing that the number of female entrepreneurs with a so-called Turkish background is, in comparison to other groups, one of the lowest.

Since, however, we wanted not to produce or reproduce ethnic or nationalist categories, we tried to overcome such methodological 'groupism' by taking spatial units (Glick Schiller and Caglar 2013) as a starting point. ${ }^{6}$ We selected different streets in different areas of Vienna known to be localities with many so-called migrant businesses and found respondents by surveying the streets and calling in to their shops (see also Rusinovic 2008). We focused on businesses like food wholesalers, catering services, hairdressers and other areas in which, according to the literature, migrants are active because they need little start-up capital and are not heavily regulated (Schmatz and Wetzel 2014, p. 36 f.). It was, however, important that women own the businesses. Altogether we conducted 15 narrative interviews, which took between one and two and a half hours. With the approval of the interview partners, each interview was recorded and anonymised. It is important to highlight that finding shops owned by women was not easy. Most of the shops into which we called were owned by men, supporting the findings by Schmatz and Wetzel (2014) cited above. Second, many female entrepreneurs were reluctant to give an interview, were too busy to find

${ }^{5}$ For a more differentiated discussion of the areas of activity involved (with regard also to nationality), see Schmatz and Wetzel 2014.

${ }^{6}$ See also Hillmann (2011) for such an approach. 
a time slot for an interview, or both, whereas others were very open and invested quite a bit of their time. It has to be stated that the degree of openness was influenced by who called into their shops. The team consists of two researchers, one belonging to the host society and the other having a migrant background. The migrant background of one of the researchers, as well as the gender dimension, definitely made access easier due to her being presumed an 'insider'. ${ }^{7}$ This also, however, made for an ambivalent position since the perceived status vis-à-vis the research participants had to be renegotiated constantly (Shinozaki 2012; Nowicka and Ryan 2015). The positioning of the researchers, since knowledge is 'situated' (Haraway 1988), thus influenced not only the conceptualisation of the research and the analysis, but also the empirical phase, especially since the ways that interview partners perceived the interviewers influenced what they said and how (Holstein and Gubrium 2003).

The female migrant entrepreneurs interviewed were very heterogeneous with regard to the activities in which they were involved. They run businesses in the catering, tailoring, hairdressing and massage sectors; so, sectors that are generally said not to be 'traditionally male dominated' (Pardo-del-Val 2010, p. 1481). Half of the women had themselves migrated, whereas the others were born in Austria, some having Austrian citizenship. All but one had children but not all were married. One woman was a widow, two were divorced, one unmarried and 11 were married to men who also had, according to the women, a history of mobility. All were owners of small enterprises that they had been running for between two and eight years, and only three were employers. With regard to age there was a wide range: The youngest interviewee was 29 years old and the oldest was in her mid-fifties. None of the interviewed women had the sort of 'standardised biographies' often constructed for male entrepreneurs, i. e. starting a business with a financial cushion under favourable social and political conditions (Kreide 2003).

In the following sections, we present and discuss categories and respective themes that arose in many of the interviews and related to our academic interest. Mobility was explicitly and implicitly an issue throughout the interviews and analysis; not in the sense that spatial or social mobility was mentioned or constantly referenced by the female migrant entrepreneurs but that, like gender, was obviously a structuring dimension with regard to their social and economic lives, a key difference and otherness "producing machine" (Salazar and Smart 2011, p. v). Both dimensions were referred to in order to differentiate themselves from 'others' (be they the ostensibly immobile majority group, men in general, or their defined 'ethnic' group), and thus constitute an important aspect of their identity construction and positioning as entrepreneurs.

\footnotetext{
${ }^{7}$ For a thorough discussion of who is considered an 'insider' and who an 'outsider' in migration research, see the articles in the Journal of the Forum of Qualitative Social Research, Vol. 16, No. 2, 2015.
} 


\section{Mobility, its Meaning and Embeddedness: Empirical findings}

\subsection{Mobility as qualification and success}

In nearly all the interviews the ability to take risks and to cope with the threats as well as the opportunities that arise from becoming self-employed was embedded by the women interviewed into their particular mobility histories. Their different work attitudes like being flexible and innovative, defined as a precondition for becoming selfemployed, were constructed as a result of their or their parents' spatial mobility and as the only possibility to achieve social mobility in a societal context where opportunities were limited for them. The spatial mobility as well as experiences and challenges that accompanied this process were 'transformed' and presented as 'mobility capital'. ${ }^{8}$ The latter favours self-employment, which is seen by the interview partners as a way to position them economically as well as socially. Thus, working hard as well as taking risks were highlighted as the result of spatial mobility and accordingly not only part of their self-perception but defined as a specific qualification necessary to become a 'successful' entrepreneur.

Success was considered by most of the interview partners as making a living from the economic activities they have initiated and 'surviving' despite economic difficulties. Sara, who owns a Thai massage business, says: "I am proud that my business is running now for 5 years although many of the newly founded businesses have to close after the first year. It's the idea and the power you have because I and my family had to fight here in Austria". It must also be stated, however, that all but three of the women interviewed still have to struggle. Most of the women, while presenting their enterprise as a success, also explained that they and their families could not survive from the income they earn through their economic activities alone. It's therefore not the financial benefit alone but, furthermore, the personal and symbolic factors relating to self-employment that are of importance, as the interviews reveal. Selfemployment was presented a self-fulfilling model of economic activity and a possibility for social mobility that allowed for both combining the various responsibilities with which the women see themselves confronted and using their 'mobility capital'. Several studies on female migrant entrepreneurs come to similar conclusions (see Anthias and Metha 2003 or Verduijn and Essers 2013). However, this finding is not meant to support the neo-liberal position that entrepreneurship, especially for female migrants, in itself implies empowerment but it shows that gender is central to understanding entrepreneurship and shed light on the social transformations that spatial mobility has initiated.

\footnotetext{
${ }^{8}$ Thanks to Sara de Jong for coming up with this term while discussing some of the empirical data. However, Kaufmann et al. in a paper in 2004 already used the phrase 'mobility as capital' in exploring and discussing the links between spatial and social mobility.
} 


\section{2 'Mobility makes the difference'-Who are the 'others'?}

What we know about entrepreneurship comes from classical economic studies. ${ }^{9}$ In these studies, e. g. Bruni et al. (2004, p. 258), tendencies such as taking risks and being innovative have been identified as intrinsic to those who become successful entrepreneurs. The entrepreneur has thus emerged, in the academic as well as the public discourses, not only as more heroic than cowardly but also, as Collins and Moore (1964, S. 5) state, as "more masculine than feminine". Accordingly, the qualities necessary for entrepreneurialism have for decades been construed as masculine, which does not imply that there have not been female entrepreneurs but that up to the 1980s not much was known about them. Instead, the male gender of entrepreneurs was for decades an invisible and uncontroversial issue (Bruni et al. 2004, p. 259). Interestingly, the same qualities we find in mainstream literature on entrepreneurship (see f. ex. Landoli et al. 2007), i. e. deeply embedded in the binary gender system and constructed as masculine, are taken up by the women interviewed. The women are using the same rhetoric for describing themselves as can be find in scientific as well as public discourse on entrepreneurship, they, however, attribute these qualities not to gender but to mobility. It is first of all mobility that they employ to differentiate themselves from the 'others', i. e. the immobile Austrians who are described as too cowardly to take the step into self-employment. "They [the Austrians] are so settled, they rely on the welfare system, therefore they do not open businesses", says Nasma, who owns a catering firm. It is this differentiation that makes mobility meaningful for them, yet it also refers to attributes that the dominant discourse on entrepreneurship has been reproducing for decades.

The interviews further revealed that mobility as an important aspect of identity construction is a result of the constraints migrants experienced due to societal structures and discourses (Essers and Benshop 2009, p. 406), as well as social interactions and experiences with the immobile 'others'. The decision to become a 'successful' entrepreneur was in some cases the result of discrimination experienced in the labour market due to language problems or, as in Sara's case, to open racism. She applied for a job in a Viennese coffee house and was not hired, as she said, due to 'looking Asian'. Others said that due to a lack of vocational training they could only find jobs that were very exploitative. Liane, for example, worked in a fashion shop and states: "I had to work twice as much as the others and was not paid". Half of the women interviewed had several jobs before becoming self-employed but were very reluctant to talk about their experiences. The others had no first-hand experience on the labour market either because it was never perceived as an option, or self-employment was part of their respective family history (albeit the male family history).

\subsection{Gendering mobility capital and transnational capital}

Gender also explains why it is important to distinguish between 'transnational capital' and 'mobile capital'. As mentioned already, the mainstream literature on 'ethnic

\footnotetext{
${ }^{9}$ For a critical reflection of the 'entrepreneurial self' as the hegemonic conception see Bührmann 2005 or Bröckling et al. 2000.
} 
entrepreneurship' increasingly focuses on the transnational economic activities of so-called ethnic or migrant entrepreneurs, thereby assuming that every entrepreneur is automatically transnationally active, possessing 'transnational capital' (Rusinovic 2008; Ambrossini 2012; Portes et al. 2002; Zhou 2004). Our interviews have, however, shown that transnational economic activities, transnational capital, or transnational links do not play a significant role in the economic activities of female entrepreneurs. In fact, the women interviewed mentioned hardly any transnational involvement. Only two of the female entrepreneurs imported goods from their socalled countries of origin or abroad. For Maria, products from her so-called country of origin (Poland) do not play a significant role in her entrepreneurial activities, although she imports clothes from other European countries. Maria describes herself as being transnationally active by going to Cologne, Germany, in order to buy cheap clothes for her business in Vienna. As she explains: "In Austria it is too expensive! In Cologne, there is an exhibition, a major exhibition, and things there are cheap and the quality is better. I do not have to go to the third district to the wholesalers. Nowadays one is flexible". Sue, who owns a Chinese restaurant, also imports goods but not through travelling herself. She is instead engaged in "commercial transnationalism" (Ambrossini 2012), which means she imports products from China, primarily spices since, she maintains, they are what make her dishes special. This commercial transnationalism strengthens the 'othering' of the female entrepreneur, since she serves and presents for her customer 'the other and exotic world'. Sara on the other hand travels for economic reasons since she and her employees regularly go to China to receive training on massage techniques and acquire the knowledge and skills to carry out massages properly. "My customers expect Asian massage. Therefore we had and have to learn the necessary skills, which cannot be done in Austria”, she says. This direct transnational transfer of knowledge and skills through travelling is not only central to her economic activities but has become a crucial factor for identity construction and for positioning herself locally. She very clearly pointed out that she had to learn these skills and transferred the expectations and the 'othering' she experienced into a business. It became an important aspect of her entrepreneurial identity. Surprisingly ${ }^{10}$, the interviews further reveal that only a few female entrepreneurs hold transnational ties to relatives in their so-called countries of origin and that none of these contacts were directly relevant to their economic activities in Vienna. Some of the female entrepreneurs, however, own land and houses in their so-called countries of origin. This 'strategy' seems to be closely related to their constructed identities, with mobility and transnational elements as part of it. To be risk-taking and flexible meant in some cases not only to think of opening another business in Vienna or of moving to a different sector but, furthermore, to imagine going 'back' to their socalled countries of origin. Liane, who grew up in Austria, explained that she could imagine going to Turkey in the future. "I do not see any future here. Turkey is larger; in Turkey you would have more chances. It is more beautiful, the weather is beautiful, you have the sea. I find the schools better, the training there, because here the children have to deal with 'Are you a Turk? What is your mama, your daddy? Are they

\footnotetext{
10 'Surprisingly' refers here to the expectations the researchers had due to academic and public discourse on migrants in general, and migrant entrepreneurs and the importance of transnational ties.
} 
guest workers?' [...] In Turkey you are a Turk! It is just better there than here. You are excluded due to stereotyping. There you do not have this problem, you are local". She further assumes that the economic opportunities for a female entrepreneur are better in Turkey. For her, mobility is not only life-shaping but, furthermore, an important element in imagining a better future.

In the interviews, 'mobile capital' rather than 'transnational capital' (Rusinovic 2008) turned out to be important for the women's positioning of themselves and to imagining a better future. 'Mobile capital' links spatial and social mobility and refers to the interchangeability of different forms of mobility (see Kaufmann et al. 2004). Mobility in its different forms becomes thus a symbolic element for imagining a better future and overcoming inequalities.

\subsection{Support, networks and gender-relations}

The interviews further revealed that, besides one women, none could rely on support or financial capital from their 'communities' or so-called ethnic networks (see also Anthias and Mehta 2003). Zeynep, who owns a catering business, states for example: "I did everything alone, nobody supported me. But that is fine-I am very strong. People thought I could not manage but I can". This is definitely one reason why they started businesses that did not need much start-up capital. ${ }^{11}$ This overall lack of support from their families and the broader community explains why, in the case of this study, mobility and not 'ethnicity' became an important marker for identity construction and, furthermore, why relations with their male family members were a recurrent theme in the interviews.

The lack of family or male support at the same time creates room for manoeuvre; most women pointed out that because of this they do not want to involve their families or husbands in their businesses. This could however also be read as a strategy to legitimise their activities, as does the reference to Austria's 'gender order': "We are in Austria. Here women can be self-employed. At home (in Turkey) the situation is different so I do not say much when we go there for vacations." Others, like Lisa, justify their self-employment by focusing on personal attributes: "I am alone; I am a strong, very strong woman. A man here would be a barrier". Still others state that since men do not like strong women it is better to do it without men. Differentiating themselves from their male counterparts or family members seems to be important for developing an entrepreneurial identity. Says Zeynep: "Once, my husband was working because I was sick, and all the customers were asking for me. My husband and my daughter, they could not manage it well ... I just have the whole thing under better control than my husband". This does not, however, imply a questioning of the specific gender relations and constructions of femininity, which are, although hardly ever explicitly mentioned, still as important as entrepreneurship for their identity construction and boundary-drawing. Well aware that they are stretching the boundaries of what work is acceptable for them, most of those interviewed presented themselves as devoted mothers and good housewives. Throughout the interviews, to justify their being dif-

\footnotetext{
${ }^{11}$ The majority of women also had no information about the official support available for them, or the special programs for migrant entrepreneurs that different organizations offer.
} 
ferent and crossing boundaries, it was argued that, for example, men can take over neither childcare nor the responsibilities at home. "Men can just never be as clean as women! They cannot work as accurately as women do”, says Lisa the hairdresser. "I try to spend as much time with my children as possible and try to support them in school, which is necessary because due to their background they get treated differently. My husband does not worry that much", explains Liane. The interviews also revealed that personal relations, especially between men and women, often become more difficult as the women gain increasing independence, perceived by them as social mobility, through self-employment (Anthias and Mehta 2003, p. 111). Two women stated quite openly that their husbands, afraid that the women would not be able to fulfil their responsibilities at home, did not want them to open a shop, others stated that their husbands showed not much interest as long as they, as Nasma puts it, "... nothing changes at home". It is, however, important to note that these findings are not unique to female entrepreneurs with a so-called migration background. Quite a number of studies of female entrepreneurs without a migration background come to similar conclusions and could be quoted here (Malach et al. 2010; Hancock et al. 2014; Elam 2008). This shows the importance of both integrating gender into the analysis of entrepreneurship and deconstructing gender-neutral discourses on entrepreneurship. In the case of migrant female entrepreneurs, however, an additional dimension or social process has to be taken into account; namely that their behaviour and social mobility does not correspond with how the immobile 'others' perceive gender relations among the mobile 'others'. This is experienced especially in interactions with customers. All the women interviewed opened businesses in the hope of appealing to a wide variety of customers. They were very aware that their 'ethnic' positioning is a 'selling point'. Ruth says, "Even though I do not sell Greek food, the customers still say that they remember their holidays when they have lunch here". Sara gives a detailed description of Asian massage even though she grew up in Austria and had to learn the technique. All of the women described their relations and interactions with customers, especially the 'locals', as very good; however it also became obvious that they have to cope not only with the gender expectations of their so-called community but with how the 'locals' imagine them as different in terms of assumed 'ethnic' and religious gender orders. Liane describes her experiences and interactions with the customers as follows: "Customers say 'Oh, you are not like the other Turks'. At that moment, I think to myself, 'Yes, but I am a Turk!' And, for example, comments like 'But I can give you no kiss on the cheek, because among Turks one is not allowed to, especially not to women". Mobility thus is also a way to navigate the different expectations with which they are confronted, and to distance themselves from both the 'others' and gender expectations within their 'communities'.

\section{Conclusion}

Female migrant entrepreneurs do not act in a social vacuum, but have to position themselves with regard to different gender regimes, their social reception by the majority population, and 'ethnic' and 'national' attributions and categorisations. The self-positioning of female migrant entrepreneurs is closely connected to mobil- 
ity, defined as a special 'qualification' and form of capital. Mobility rather than a multi-cultural history or 'ethnicity' was presented as a skill (Nederveen-Pieterse 2003 , p. 44). Therefore mobility in this context becomes, so this paper argues, an identity marker crucial to differentiating themselves primarily from the so-called immobile 'others' or majority 'group', coping with stigmatisation and discrimination, and positioning themselves economically as well as socially. Mobility also becomes a symbolic element in terms of imagining a better future and overcoming social inequalities. This mobility perspective, an outcome of the processes and issues we studied, allows us to overcome the 'ethnic lens' especially in studies on 'ethnic entrepreneurship'. Mobility was defined and constructed by the female migrant entrepreneurs as a competitive advantage and not, as it is often deemed, as a shortcoming. It can thus be argued that they, in a way, turned around their stigmatisation and the constructions that increasingly accompany people's spatial mobility and also question the mainstream definitions of social mobility. The meaning and negotiation of mobility demonstrates, on the one hand, women's agency, but reveals, on the other, that social inequalities and 'othering' processes are an intrinsic part of mobility. Mobility is more than spatial movement; it is especially the interface between spatial and social mobility which is important to analyze and understand the gendered meaning of social mobility in particular and the complex social configurations societies are increasingly confronted with.

Open access funding provided by University of Vienna.

Open Access This article is distributed under the terms of the Creative Commons Attribution 4.0 International License (http://creativecommons.org/licenses/by/4.0/), which permits unrestricted use, distribution, and reproduction in any medium, provided you give appropriate credit to the original author(s) and the source, provide a link to the Creative Commons license, and indicate if changes were made.

\section{References}

Aigner, Petra. 2012a. "Ethnische Unternehmen" und "Ethnic Entrepreneurship" in Österreich. IMP Working Paper No. 2. Linz: International Migration Press. http://migrationstudies.at/Ethnische_ Unternehmen_Austria.pdf. Accessed 27 Aug 2015.

Aigner, Petra. 2012b. Ethnisches Unternehmertum als Chance sozio-kultureller Integration? Entwicklung eines system- und integrationstheoretischen Modells. SWS-Rundschau 52:389-411.

Alteneder, Wolfgang, and Michael Wagner-Pinter. 2013. Ethnische Ökonomien in Wien. http://images.derstandard.at/2013/08/19/WAW_Ergebnisse\%20Studie\%20Ethnische\%20oekonomien.pdf. Accessed 9 Sept 2015.

Ambrossini, Maurizio. 2012. Migrant's entrepreneurship in transnational social fields: Research in the Italian context. International Review of Sociology 22:273-292. doi:10.1080/03906701.2012.696970.

Anthias, Floya. 1992. Ethnicity, Class, Gender and Migration. Aldershot: Ashgate.

Anthias, Floya, and Nishi Mehta. 2003. Gender, migration and a self-employment: Gender divisions and ethnic enterprise. International Review of Sociology 13:105-117. doi:10.1080/0396070032000087 014.

Apitzsch, Ursula. 2003. Gaining autonomy in self-employment processes. the biographical embeddedness of women's and migrant's business. International Review of Sociology 13:163-182. doi:10.1080/03 90670032000087041.

Azmat, Fara. 2013. Opportunities or obstacles? Understanding the challenges faced by migrant women entrepreneurs. International Journal of Gender and Entrepreneurship 5:198-215. doi:10.1108/17566261311328855.

Baycan-Levent, Tuzin. 2010. Migrant women entrepreneurs in OECD countries. In Open for Business Migrant Entrepreneurship in OECD Countries, ed. OECD, 227-254. Geneva: OECD. 
Borjas, George J. 1986. The self-employed experience of immigrants. The Journal of Human Resources 21:485-506.

Bröckling, Ulrich, Susanne Krasmann, and Thomas Lemke. 2000. Gouvernmentalität der Gegenwart. Studien zur Ökonomisierung des Sozialen. Frankfurt a. M.: Suhrkamp.

Brubaker, Rogers. 2002. Ethnicity without groups. European Journal of Sociology 43:163-189. doi: $10.1017 /$ S0003975602001066.

Bruni, Attila, Silvia Gherardi, and Barbara Poggio. 2004. Entrepreneur-mentality, gender and the study of women entrepreneurs. Journal of Organizational Change Management 17:256-268. doi: $10.1108 / 0953481041053815$.

Bührmann, Andrea. 2005. The emerging of the entrepreneurial self and its current hegemony. Qualitiative Social Research 6. http://nbn-resolving.de/urn:nbn:de:0114-fqs0501165.

Collins, Orvis, and David G. Moore. 1964. The enterprising men. Bureau of Business and Economic Research. East Lansing: Michigan State University.

Cresswell, Tim. 1999. Failing Down: Resistance as diagnostic. In Geographies of Dominational Resistance, ed. Joanne Sharp, 256-268. London: Routledge.

Elam, Amanda Brickman. 2008. Gender and entrepreneurship: A multilevel theory and analysis. Cheltenham: Edward Elgar.

Erel, Unmut. 2010. Migrating cultural capital: Bourdieu in migration studies. Sociology 44:642-660. doi: $10.1177 / 0038038510369363$.

Esser, Hartmut. 2003. Ist das Konzept der Assimilation überholt? Geographische Revue 5:5-22.

Esser, Caroline, and Yvonne Benshop. 2009. Muslim businesswomen doing boundary work: The negotiation of Islam, gender and ethnicity within entrepreneurial contexts. Human Relations 62:403-423. doi: $10.1177 / 0018726708101042$.

Fauser, Margit, Elisabeth Liebau, Sven Voigtländer, Hidayet Tuncer, Thomas Faist, and Oliver Razum. 2015. Measuring transnationality of immigrants in Germany: Prevalence and relationship of social inequalities. Ethnic and Racial Studies 38:1497-1519. doi:10.1080/1419870.2015.1005639.

Fox, Jon E., and Demelza Jones. 2013. Migration, everyday life and the ethnicity bias. Ethnicities 13:385400. doi: $10.1177 / 1468796813483727$.

Friedman, Jonathan. 2002. From roots to routes: Tropes for trippers. Anthropological Theory 2:21-36. doi $: 10.1177 / 1463499602002001286$.

Garcia-Diaz, Christina M., and Sara Carter. 2009. Resource mobilization through business owners' networks: Is gender an issue. International Journal of Gender and Entrepreneurship 1:226-252.

Glaser, Barney, and Anselm L. Strauss. 1967. The Discovery of Grounded Theory. Strategies for Qualitative Research. Chicago: Aldine.

Glick-Schiller, Nina, and Ayse Caglar. 2013. Locating migrant pathways of economic emplacement: Thinking beyond the ethnic lens. Ethnicities 13:494-514. doi:10.1177/146879681343733.

Goebel, Dorothea, and Ludger Pries. 2006. Transnationalismus oder ethnische Mobilitätsfalle? Das Beispiel des "ethnischen Unternehmertums". In Transnationale Karrieren, eds. Florian Kreutzer and Silke Roth, 260-282. Wiesbaden: VS Verlag.

Haberfellner, Regina. 2003. Austria: Still a highly regulated economy. In Immigrant Entrepreneurs. Venturing Abroad in the Age of Globalization, eds. Robert Kloosterman and Jan Rath, 213-232. Oxford: Berg.

Haberfellner, Regina, and Martina Böse. 1999. Ethnische Ökonomien. Integration vs. Segregation im Kontext der wirtschaftlichen Selbständigkeit von MigrantInnen. In Abgrenzen. Ausgrenzen. Auf-nehmen. Empirische Befunde zur Fremdenfeindlichkeit, eds. Heinz Fassmann, Helga Matuschek, and Elisabeth Menasse, Klagenfurt: Celovec.

Halkias, Daphne, and Sylva M. Caracatsanis. 2011. The evolution of researching female immigrant entrepreneurship: A commentary. In Female Immigrant Entrepreneurs. The Economic and Social Impact of a Global Phenomenon, ed. Daphne Halkias, et al., 3-7. Farnham: Gower.

Hancock, Connie, Anna Pérez-Quintana, and Ester Hormiga. 2014. Stereotypical notions of entrepreneurs: An analysis from a perspective of gender. Journal of Promotion Management 20:82-94. doi:10.108 0/10496491.2014.869100.

Hanson, Susan, and Megan Blake. 2009. Gender and entrepreneurial networks. Regional Studies 43:135149. doi: $10.1080 / 00343400802251452$.

Haraway, Donna. 1988. Situated knowledge: The science question in feminism and the privilege of partial perspective. Feminist Studies 14:575-599.

Hillmann, Felicitas. 1998. Türkische Unternehmerinnen und Beschäftigte im Berliner ethnischen Gewerbe. Berlin: WZB. 
Hillmann, Felicitas, ed. 2011. Marginale Urbanität. Migrantisches Unternehmertum und Stadtentwicklung. Bielefeld: transcript.

Holstein, James, and Jaber Gubrium. 2003. The active interviewing. In Postmodern Interviewing, eds. James Holstein and Jaber Gubrium, 67-80. Thousand Oaks: Sage.

Huysmans, Jef. 2000. The European Union and the Securitization of Migration. Journal of Common Market Studies 38:751-777.

Kaufmann, Vincent, Manfred Max Bergmann, and Dominique Joye. 2004. Motility: Mobilitiy as Capital. International Journal of Urban and Regional Research 28:754-756.

Kloosterman, Robert, and Jan Rath. 2001. Immigrant entrepreneurs in advanced economies: Mixed embeddedness further explores. Journal of Ethnic and Migration Studies 27:189-201. doi:10.1080/13691830020041561.

Klyver, Kim, and Sharon Grant. 2010. Gender differences in entrepreneurial networking and participation. International Journal of Gender and Entrepreneurship 2:213-227.

Kofman, Eleonore, Sawitri Saharso, and Elena Vacchelli. 2015. Gendered Perspectives on Integration Discourses and Measures. International Migration 53 (4): 77-89 http://onlinelibrary.wiley.com/ doi/10.1111/imig.12102/pdf. Accessed 7 Jan 2016.

Kreide, Regina. 2003. Self-employment of Women and Welfare-state Policies. International Review of Sociology 13:205-218. doi:10 1080/0390670032000087069.

L \& R Sozialforschung. 2007. Ethnische Ökonomien-Bestand und Chancen für Wien. Wien: L \& R Sozialforschung.

Landoli, Luca, Hans Landstrom, and M. Raffa. 2007. Entrepreneurship and economic growth. Cheltenham: Edward Elgar.

Light, Ivan, and Steven Gold. 2000. Ethnic Economies. San Diego: Academic Press.

Malach Pines, Ayala, Miri Lerner, and Dafna Schwartz. 2010. Gender differences in entrepreneurship: Equality, diversity and inclusion in times of global crisis. Equality, Diversity and Inclusion: An International Journal 29:186-198.

Morokvasic, Mirjana. 1991. Roads to Independence. Self-Employed Immigrant and Minority Women in Five European States. International Migration 29:407-419.

Nederveen Pieterse, Jan. 2003. Social capital and migration. Beyond ethnic economies. Ethnicities 3:2958. doi:10.1177/1468796803003001785.

Nowicka, Magdalena, and Louise Ryan. 2015. Beyond insiders and outsiders in migration studies: Rejecting priori commonalities. Forum Qualitative Social Research 16:18.

Nuscheler, Franz. 2004. Internationale Migration, Flucht und Asyl. Wiesbaden: VS Verlag.

Pardo-del-Val, Manuela. 2010. Services supporting female entrepreneurs. Service Industries Journal 30:1479-1498. doi:10.1080/02642060802626840.

Pfaff-Czarnecka, Joanna. 2013. Multiple belonging and the challenges to biographic navigation. MMG Working Paper 13. Göttingen: Max Planck Institute for the Study of Religious and Ethnic Diversity.

Phizacklea, Annie. 1983. One Way ticket: Migration and Female Labour. London: Routledge.

Pio, Edwina. 2007. Ethnic minority migrant women entrepreneurs and the imperial imprimatur. Women in Management Review 22:631-648. doi:10.1108/09649420710836317.

Portes, Alejandro, William J. Haller, and Luis Eduardo Guarnizo. 2002. Transnational entrepreneurs: The emergence and determinants of an alternative form of immigrants' economic adaption. American Sociological Review 67:278-298.

Reevy, Gretchen M., and Christina Maslach. 2001. People's use of social support: Gender and personality differences. Sex Roles 44:437-459.

Rusinovic, Katja. 2008. Transnational embeddedness: Transnational activities and networks among firstand second-generation immigrant entrepreneurs in the Netherlands. Journal of Ethnic and Migration Studies 34:431-451. doi:10.1080/13691830701880285.

Salazar, Noel, and Alan Smart. 2011. Introduction. Anthropological Takes in (Im)Mobility. Identities: Global Studies in Culture and Power 18:i-ix. doi:10.1080/1070289X.2012.683674.

Schinozaki, Kyoko. 2012. Transnational dynamics in researching migrants: Self-reflexivity and boundary drawing in fieldwork. Ethnic and Racial Studies 35:1810-1827. doi:10.1080/01419870.2012.6592 75.

Schmatz, Susi, and Petra Wetzel. 2014. Migrantische Ökonomien in Wien. Wien: Kammer für Arbeiter und Angestellte in Wien.

Schütz, Alfred. 1971. The Problem of Social Reality. Collected Papers. vol. 1. The Hague: Martinus Nijhoff. 
Schütz, Alfred, and Thomas Luckmann. 1979. Strukturen der Lebenswelt. vol. 1. Frankfurt a. M.: Suhrkamp.

Sheller, Mimi, and John Urry. 2006. The new mobilities paradigma. Environment and Planning 38:207226. doi: $10.1068 / \mathrm{a} 37268$.

Verduijn, Karen, and Caroline Essers. 2013. Questioning dominant entrepreneurship assumptions: The case of female ethnic minority entrepreneurs. Entrepreneurship and Regional Development 25:612630. doi:10.1080/08985626.2013.814718.

Vigh, Henrik. 2009. Motion Squared. A second look at the concept of social navigation. Anthropological Theory 9:419-438. doi:10.1177/1463499609356044.

Volery, Thierry. 2007. Ethnic entrepreneurship: A theoretical framework. In Handbook of Research on Ethnic Minorities, ed. Dana Leo-Paul, 30-41. Cheltenham: Edward Elgar Publishing.

Waldinger, Roger, Howard Aldrich, and Robin Ward. 1990. Ethnic Entrepreneurs. Immigrant Business in Industrial Societies. Newburg Park: Sage.

Wien, Stadt. 2012. Monitoring Integration, Diversität, Wien 2009-2011. Wien: Magistratsabteilung 17.

Wimmer, Andreas, and Nina Glick Schiller. 2003. Methodological nationalism, the social sciences, and the study of migration: An essay in historical epistemology. International Migration Review 37:576-610.

Zhou, Min. 2004. Revisiting ethnic entrepreneurship: Convergences, controversies, and conceptual advancements. International Migration Review 38:1040-1074. doi:0197-9183/04/3803.01.0147.

Petra Dannecker is professor of development sociology and head of the Department of Development Studies of the University of Vienna. She is working on issues related to development sociology, development politics, globalization, migration and gender. She is also a key researcher of the research platform 'Mobile Cultures and Societies Interdisciplinary Studies on Transnational Formations', which investigates phenomena and conditions of cultural and social mobility.

Alev Cakir studied Political Science at the University of Vienna as well as Peace and Conflict Studies at the University of Innsbruck. She is University Assistant(prae-doc) at the research platform 'Mobile Cultures and Societies. Interdisciplinary Studies on Transnational Formations' and PhD student as well as University lecturer at the Department of Political Science at the University of Vienna. 